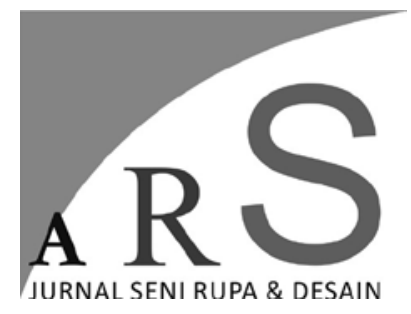

Vol 24 No 1 Januari - Maret 2021 43-50

\section{RUANG DIGITAL PADA PAMERAN UNIT KEGIATAN MAHASISWA MULTIMEDIA ITB STIKOM BALI}

\author{
Ni Wayan Setiasih \\ Program Studi Sistem Informasi, Fakultas Informatika dan Komputer, \\ Institut Teknologi dan Bisnis STIKOM Bali \\ Tlp.085935007552,E-mail: setiasih@stikom-bali.ac.id
}

\begin{abstract}
ABSTRAK
Berkarya pada masa pandemi dengan kondisi yang serba terbatas dapat dilakukan dengan memanfaatkan teknologi multimedia. Sebagai bentuk perhatian terhadap pemanfaatan teknologi ini, maka Unit Kegiatan Mahasiswa Multimedia periode 2019/2020 mengadakan kegiatan MAHAKARYA MULTIMEDIA 2020 (Webinar dan Pameran Digital). Tujuan utama kegiatan adalah membahas pemanfaatan teknologi multimedia sebagai media penciptaan hingga pada pemasaran karya seni. Kajian terhadap kegiatan tersebut penting untuk dilakukan agar proses pelaksanaannya dapat dijadikan referensi untuk kegiatan-kegiatan lainnya. Metode kajian yang digunakan adalah metode deskriptif analitik, yaitu metode yang mendeskripsikan secara terstruktur dan sistematis keadaan yang sedang berlangsung dengan berdasar fakta yang terjadi. Dalam event ini terdapat Webinar dan Pameran Digital. Pada Webinar dan Pameran Digital akan mendatangkan pembicara/narasumber dari kalangan dunia industri yang bergerak pada bidang seni dan bisnis digital. Sedangkan, pada pameran akan dilakukan secara online dimana karya karya terbaik dari anggota maupun pengurus akan ditampilkan pada platform media sosial. Adapun pengelolaan dalam pameran meliputi: adanya pengelolaan terhadap sumber daya manusia, adanya perencanaan, pengorganisasian, pengumpulan sumber daya, pengendalian kerja, dan pengawasan.
\end{abstract}

Kata kunci: ruang digital, pameran digital, UKM multimedia

\begin{abstract}
Digital Space at ITB Stikom Bali Multimedia Student Activity Unit Exhibition. Working during a pandemic with limited conditions can be done by utilizing multimedia technology. As a form of concern for the use of this technology, the Multimedia Student Activity Unit for the period 2019/2020 held MAHAKARYA MULTIMEDIA 2020 (Webinars and Digital Exhibitions). The main objective of the activity is to discuss the use of multimedia technology as a medium for creation to marketing of works of art. It is important to conduct a study of these activities so that the implementation process can be used as a reference for other activities. The study method used is descriptive analytic method, which is a method that describes the ongoing situation in a structured and systematic manner based on the facts that occur. In this event there are Webinars and Digital Exhibitions. The Webinars and Digital Exhibitions will bring in speakers / resource persons from the industrial world who are engaged in digital arts and business. Meanwhile, the exhibition will be conducted online where the best works of members and management will be displayed on social media platforms. The management in the exhibition includes: management of human resources, planning, organizing, gathering resources, controlling work, and monitoring.
\end{abstract}

Keywords: digital space, digital exhibition, multimedia student activity unit 


\section{Pendahuluan}

Perkembangan teknologi multimedia saat ini menjadi andalan utama dalam penyebaran bermacam informasi, termasuk dalam hal ini adalah pada bidang seni. Berbagai kelebihan teknologi multimedia dapat digunakan untuk menciptakan karya atau bahkan sampai dengan memasarkannya kepada masyarakat luas.

Pada masa pandemi sangat terlihat kelebihan bidang multimedia, yaitu mampu menjadi sarana penciptaan karya seni yang hasilnya dapat dinikmati masyarakat luas dengan meminimalisir kedekatan secara fisik. Kesempatan untuk berkarya mencakup kalangan yang lebih luas karena dimudahkan oleh teknologi digital. Kesempatan demikian juga dapat dimanfaatkan untuk pengembangan pada dunia pendidikan dan dunia kerja.

Kesempatan kerja yang semakin sempit pada masa pandemi membutuhkan orang-orang yang mempunyai kreativitas ekstra agar tetap mampu bertahan. Kecanggihan teknologi multimedia dapat menjadi solusi untuk mengembangkan kreativitas tersebut sekaligus mendapatkan penghasilan dari karya yang dihasilkan.

Bertujuan untuk mengkaji secara lebih mendalam tentang teknologi multimedia dan karya seni maka perlu diadakan suatu event atau acara yang membahas tentang hal tersebut. Wujud dari acara dimaksud adalah webinar dengan pertimbangan kondisi masa pandemi. Dari pelaksanaan webinar peserta akan mendapatkan wawasan mengenai trend pasar, agar lebih bisa mengelola karya-karya yang mereka buat. Harapannya bahwa peserta dapat memperoleh pundi-pundi penghasilan dari karya tersebut di tengah kondisi yang terbatas. Jadi mereka tidak hanya sekedar berkarya tetapi juga mampu mengimplementasikan secara langsung menjadi sebuah bisnis.

Selain itu, karya-karya yang diciptakan tentu layak untuk diapresiasi dan dipamerkan dalam bentuk pameran seni secara digital. Pameran seni memang sudah biasa didengar dan ditemui pada kalangan masyarakat atau komunitas tertentu. Pameran ini merupakan pameran yang sedikit berbeda dari yang biasanya, yaitu akan mengkolaborasikan ragam karya seni dari berbagai aspek multimedia oleh para Mahasiswa, Ormawa ITB STIKOM Bali, serta dari berbagai organisasi atau komunitas luar kampus ITB STIKOM Bali. Pada pameran ini akan dipilih karya-karya terbaik lalu akan dipertunjukkan melalui platform media sosial Instagram.

Berangkat dari hal tersebut Unit Kegiatan Mahasiswa (UKM) Multimedia ITB STIKOM Bali periode 2019/2020 kemudian mengadakan kegiatan MAHAKARYA MULTIMEDIA 2020 (Webinar dan Pameran Digital). Kegiatan ini diharapkan mampu menjadi ajang untuk memperkenalkan dan mengapresiasi hasil karya seni, serta memotivasi generasi muda untuk lebih banyak berinovasi, khususnya dalam bidang multimedia.

\section{Pembahasan}

Unit Kegiatan Mahasiswa (UKM) Multimedia merupakan salah satu UKM yang tergabung dalam bidang minat dan bakat yang ada di STMIK STIKOM Bali. UKM Multimedia memiliki Visi, yaitu: menjadi Unit Kegiatan Mahasiswa yang berperan sebagai wadah penyalur minat dan bakat mahasiswa di bidang ilmu Multimedia yang mandiri, kreatif, dan inovatif yang akan menjadi bekal ilmu oleh seluruh anggota Unit Kegiatan Mahasiswa Multimedia. Sedangkan misi UKM Multimedia adalah: (1) Membekali anggota UKM Multimedia dengan pribadi budi pekerti luhur, akhlak mulia, mandiri, iman dan taqwa kepada Tuhan Yang Maha Esa; (2) Memberikan ilmu di bidang Multimedia kepada anggota UKM Multimedia berbasis Teknologi Informasi dan Komunikasi; (3) Mengembangkan potensi serta kreativitas yang dimiliki anggota di bidang Multimedia dengan mengikuti pelatihan rutin maupun tugas; (4) Mengembangkan sifat pro-aktif untuk memperdalam kemampuan anggota UKM Multimedia dengan membuat karya dan desain kreatif; dan (5) Mengembangkan jiwa kompetisi anggota UKM Multimedia secara sehat dengan berpartisipasi dalam berbagai kegiatan dan event 
di bidang Multimedia.

\section{Manajemen Pameran}

Menurut George R. Terry, dalam bukunya: "Principles of Management" memberikan definisi manajemen sebagai berikut: manajemen adalah suatu proses yang membeda-bedakan atas perencanaan, pengorganisasian, penggerakan, pelaksanaan, dan pengawasan, dengan memanfaatkan baik ilmu maupun seni, agar dapat menyelesaikan tujuan yang telah ditetapkan sebelumnya (Manullang, 2001). Merujuk dari definisi di atas, maka manajemen dipandang sebagai suatu proses mulai dari tahapan perencanaan, pengorganisasian, penggerakan, pelaksanaan, dan sampai pada pengawasan.

Sedikit berbeda dengan pendapat Hani Handoko yang menyebutkan bahwa fungsi atau prinsip manajemen itu ada 5, yaitu planning, organizing, staffing, directing/leading, dan controlling (Prasetya, 2008). Secara lebih sederhana, Geoge R. Terry yang dikutip oleh

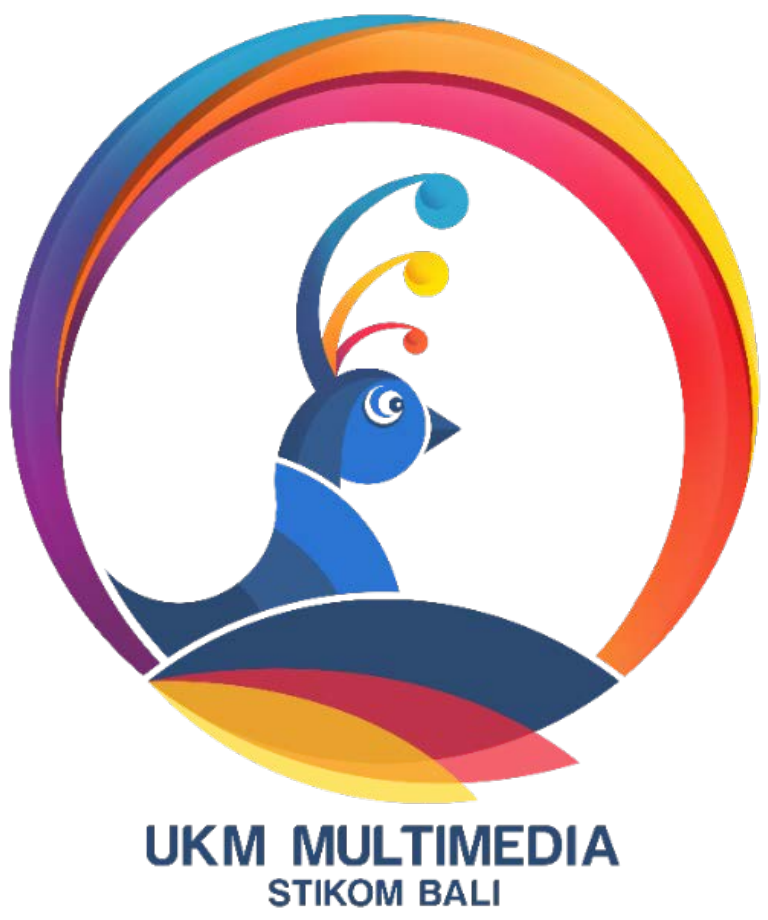

Gambar 1. Logo UKM Multimedia

(Sumber: Penulis, 2020)
Hasibuan (Hasibuan, 2014) dalam buku Manajemen Dasar, Pengertian dan Masalah, menyebut bahwa manajemen hanya dibagi menjadi 4 bagian yakni planning (perencanaan), organizing (pengorganisasian), actuating (pelaksanaan) dan controlling (pengawasan).

Perencanaan meliputi serangkaian keputusan termasuk penentuan-penentuan tujuan, kebijaksanaan, membuat program-program, menentukan metode, dan prosedur serta menetapkan jadwal. Dalam hal perencanaan, UKM Multimedia telah merencanakan pameran yang bertemakan "Pameran Digital dalam Dimensi Karya", tema ini sudah dipikirkan secara matang dan seksama. Kemudian menentukan program apa saja yang harus dilakukan terkait dengan penyelenggaraan pameran. Ada beberapa program kegiatan yang sudah dirancang seperti: mengadakan diskusi tentang multimedia dan pameran digital. Semua kegiatan di atas sudah diatur sedemikian rupa sehingga metode, prosedur dan waktu pelaksanaan kegiatan sudah ditentukan dengan jelas agar masyarakat luas tahu akan informasi yang disebarkan lewat media publikasi seperti media sosial.

Pengorganisasian berhubungan dengan pengaturan struktur melalui penentuan kegiatan untuk mencapai tujuan pada suatu badan usaha secara keseluruhan atau setiap bagian. Dalam kegiatan pameran yang diselenggarakan oleh UKM Multimedia, pengorganisasian dilakukan dengan pengaturan struktur kepanitiaan dan kegiatan, sebagaimana mengatur sumber-sumber yang dibutuhkan termasuk sumber daya manusia yang sesuai dengan kemampuannya dalam bidang masing-masing. Selain itu juga mengatur kegiatan yang sudah dirancang sedemikian rupa dengan pertimbangan-pertimbangan yang matang seperti : merencanakan kegiatan pameran digital, tentu harus diatur hari pelaksanaannya, peserta, kelengkapan alat dan bahan, sehingga kegiatan tersebut berjalan dengan lancar sesuai dengan rencana.

Pengumpulan sumber daya (Assembling Resources) yang dimaksud adalah mengumpulkan sumber daya yang meliputi personal, 
uang/kapital, alat-alat/fasilitas, dan hal-hal lain yang diperlukan untuk melaksanakan rencana. Pengumpulan sumber daya dalam kegiatan pameran yang bertemakan "Pameran Digital dalam Dimensi Karya" telah direncanakan dan ditentukan berupa sumber pendanaan utama yang berasal dari pendanaan kampus disesuaikan dengan Rencana Anggaran Belanja. Penyediaan alat-alat/fasilitas yang meliputi sound system, peralatan pemajangan karya dan yang lainnya sudah disiapkan oleh seksi perlengkapan sehingga dalam proses pelaksanaannya tidak akan terhambat oleh kurangnya persiapan kelengkapan sebagaimana yang telah direncanakan.

Pengendalian kerja (supervising) adalah bimbingan pada pelaksanaan kerja harian termasuk memberikan instruksi, motivasi agar pelaksana secara sadar mematuhi instruksi, mengadakan berbagai kordinasi pada tugas dan memelihara hubungan baik antara atasan dengan bawahan. Dalam hal ini, atasan atau ketua panitia pameran sangat berperan penting atas pengawasan dan pengendalian kerja yang dilakukan olah setiap seksi. Pengendalian kerja sebagaimana yang dipaparkan tersebut tujuannya adalah untuk menjaga kemungkinan agar setiap pekerjaan yang dilakukan terarah sesuai dengan rencana. Ketua panitia juga berhak memberikan instruksi dan motivasi pada anggotanya ketika ada penyimpangan atau ketidakpahaman atas pelaksanaan pekerjaan. Tujuannya adalah agar bawahan dapat mempertanggungjawabkan tugastugasnya dengan baik.

Bagian atau fungsi manajemen yang terakhir adalah Pengawasan (controlling), yaitu tindakan penilaian/perbaikan terhadap bawahan untuk menjamin agar pelaksanaannya sesuai dengan rencana. Jadi penilaiannya apakah hasil pelaksanaannya tidak bertentangan dengan sasaran dan rencana yang telah ditentukan. Pembetulan penyimpangan-penyimpangan tersebut akan dapat membantu dan menjamin penyelesaian daripada rencana itu.

Dalam kegiatan pameran, pengawasan sangatlah penting dilakukan terutama dalam hal pelaksanaan pekerjaan dari masing-masing bidang yang ditentukan. Koordinasi dan komunikasi adalah kunci dari pengawasan, tanpa adanya koordinasi dan komunikasi maka, jika ada penyimpangan akan sulit dibenahi dan pengawasan dianggap gagal. Seperti contoh, ketika dalam mempersiapkan segala sesuatu untuk kelengkapan alat dan bahan tentu kita harus membelinya, dalam hal ini ketua panitia meminta bawahannya untuk membelinya. Setelah bahan terbeli, maka ketua panitia meminta bukti pembelian barang berupa kuitansi, sebagai suatu bentuk dari pengawasan agar potensi penyimpangan dapat terhindari karena tanda bukti pembayaran tersebut sangat penting dalam pertanggungjawaban akhir. Jadi pengawasan dimaksudkan untuk mencegah atau memperbaiki kesalahan, penyimpangan, ketidak-sesuaian, penyelewengan dan lainnya yang tidak sesuai dengan tugas dan wewenang yang telah ditentukan. Pengawasan juga bukan berarti mencari kesalahan terhadap orang, tetapi mencari kebenaran terhadap hasil pelaksanaan pekerjaan yang telah dilakukan. Pentingnya pengawasan terhadap kinerja sangat mempengaruhi akan keberhasilan rencana yang telah ditentukan sebelumnya.

\section{Analisis SWOT}

Suatu organisasi tentu didasari atas visi dan misi sehingga apa yang direncanakan dalam sebuah organisasi khususnya dalam seni adalah sebuah keberhasilan serta apa yang menjadi tujuan yang mendasar dalam organisasi tersebut. Untuk itu, organisasi dipandang perlu dianalisis dan dievaluasi secara menyeluruh melalui Teori SWOT, agar dapat mengetahui masalah-masalah yang dihadapi. Analisis SWOT (SWOT analysis) yakni mencakup upaya-upaya untuk mengenali kekuatan, kelemahan, peluang, dan ancaman yang menentukan kinerja perusahaan. Informasi eksternal mengeni peluang dan ancaman dapat diperoleh dari banyak sumber, termasuk pelanggan, dokumen pemerintah, pemasok, kalangan perbankan, rekan diperusahaan lain. Banyak perusahaan menggunakan jasa lembaga pemindaian untuk memperoleh keliping surat 
kabar, riset di internet, dan analisis tren-tren domestik dan global yang relevan (Richard, 2010) Analisis SWOT membandingkan antara faktor eksternal peluang (opportunity) dan ancaman (threats) dengan faktor internal kekuatan (strenght) dan kelemahan (weakness).

Kekuatan (Strength). UKM Multimedia merupakan salah satu unit kegiatan di Kampus Institut Teknologi dan Bisnis STIKOM Bali. Jika diukur dari segi kekuatannya, tentu UKM Multimedia berbasiskan multimedia yang berbasis digital, terlebih lagi sebagaian besar mahasiswa ITB STIKOM Bali sebagian besar menggunakan teknologi. Dalam pameran berbasis digital, dimasa pandemi merupakan suatu kekuatan pada masa seperti ini. Dari segi teknis dalam penciptaan seni, setiap seniman dalam organisasi ini memiliki potensi atau kekuatan tersendiri dari penguasaan teknik seninya terlebih lagi penguasaan metode-metode tradisi yang digabungkan dengan modern yang didapat pada bangku kuliah dapat memperkaya khasanah ilmu dalam berperaktek seni dan konsep dalam mematangkan hasil karya yang diciptakan. Kreativitas juga sangat menentukan dalam menciptakan karya seni yang unik dan menarik. Dalam pameran digital UKM Multimedia, kreativitas dalam berbagai hal dalam seni menjadi kekuatan seperti adanya kegiatan diskusi seni, webinar dan pameran digital.

Kelemahan (Weaknesses). Tentu dalam organisasi apapun sedikit tidaknya memiliki suatu kekurangan atau kelemahan yang harus sesegera mungkin dicarikan solusinya dan ditanggulangi agar kelemahan tersebut tidak menjadi penyakit yang menyebabkan kemerosotan dalam organisasi. Pameran Digital ini memiliki kelemahan yakni tidak ada interaksi antara si pengunjung dengan si pencipta karya.

Kesempatan (Opportunity). Dengan adanya penyelenggaraan pameran yang bertemakan "Pameran Digital", selain menciptakan ruang kreativitas, tentu dapat mempublikasikan atau menjadi ajang gelar karya yang bisa diapresiasi oleh masyarakat umum. Kesempatan inilah yang harus dimanfaatkan semaksimal mungkin, serta
Tabel 1. Susunan Acara

(Sumber: Penulis, 2020)

\begin{tabular}{cccl}
\hline NO & WAKTU (WITA) & $\begin{array}{c}\text { DURASI } \\
\text { (MENIT) }\end{array}$ & \multicolumn{1}{c}{ ACARA } \\
\hline 1 & $10.00-10.10$ & 5 & Video Opening \\
\hline 2 & $10.10-10.15$ & 5 & $\begin{array}{l}\text { Sambutan Kepala Bagian } \\
\text { Kemahasiswaan }\end{array}$ \\
\hline 3 & $10.15-10.20$ & 5 & Profile Moderator \\
\hline 4 & $10.20-10.25$ & 5 & Profile Pembicara \\
\hline 5 & $10.25-11.25$ & 45 & $\begin{array}{l}\text { Pemaparan Materi } \\
\text { Pembicara } \\
\text { Basic Coloring }\end{array}$ \\
\hline 6 & $11.25-11.45$ & 20 & Sesi Tanya Jawab \\
\hline 6 & $11.45-11.50$ & 5 & $\begin{array}{l}\text { Penyerahan kenang - } \\
\text { kenangan }\end{array}$ \\
\hline 7 & $12.05-12.20$ & 15 & Penyerahan Hadiah \\
\hline 8 & $09.00-16.00$ & 420 & Repost Karya \\
\hline
\end{tabular}

kegiatan pameran haruslah berkelanjutan dari tahun ke tahun. Pada masa seperti ini, merupakan salah satu pengupaya dari pencegahan terjadinya penyebaran virus.

Ancaman (Threat). Ancaman bisa saja terjadi kapanpun yang sifatnya tak terduga dalam suatu organisasi seperti UKM Multimedia yaitu, ada dua macam ancaman yang harus dihindari. Pertama ancaman intrinsik yaitu ancaman dari dalam organisasi seperti adanya kevakuman (stagnasi) yang dapat membuat organisasi berada di suatu fase kritis seperti ketiadaan kegiatan, kurangnya interaksi dari anggota, atau kurangnya waktu untuk berdiskusi dalam merencanakan proyek ke depan. Sedangkan ancaman ekstrinsik atau ancaman dari luar dapat berupa adanya tawaran yang menggiurkan dari kelompokkelompok lain, persaingan antar kelompok, dan menjamurnya organisasi seni di lingkungan yang sama. Semua itu adalah bentuk ancaman yang harus dipikirkan agar ke depannya eksistensi suatu organisasi dapat tetap langgeng dengan cara memprogramkan kegiatan-kegiatan yang bersifat kreatif dan inovatif. 
Agenda acara itu sendiri disusun seperti yang diperlihatkan pada Tabel 1. Penyelenggaraan kegiatan tersebut didasarkan pada 3 hal, yaitu: (1) sebagai Program Kerja Unit Kegiatan Mahasiswa Multimedia ITB STIKOM Bali tahun 2019/2020; (2) Statuta ITB STIKOM Bali tahun 2019; dan (3) AD/ART Unit Kegiatan Mahasiswa Multimedia ITB STIKOM Bali. Sedangkan sasaran dan target peserta MAHAKARYA MULTIMEDIA 2020 (Webinar dan Pameran Digital) ini adalah mahasiswa/i ITB STIKOM Bali dan mahasiswa/i setingkat universitas dan perguruan tinggi di Indonesia serta masyarakat umum yang berjumlah \pm 150 orang. Kegiatan tersebut dilaksanakan pada hari Minggu-Senin, 08- 09 November 2020, pukul 10.00 WITA - selesai secara daring.

MAHAKARYA MULTIMEDIA 2020 (Webinar dan Pameran Digital) ini merupakan salah satu event dari program kerja Unit Kegiatan Mahasiswa Multimedia ITB STIKOM Bali periode 2019/2020. Dalam event ini terdapat Webinar dan Pameran Digital. Pada Webinar dan Pameran Digital akan mendatangkan pembicara/narasumber dari kalangan dunia industri yang bergerak pada bidang seni dan bisnis digital. Sedangkan, pada Pameran akan dilakukan secara online dimana karya karya terbaik dari anggota maupun pengurus akan ditampilkan pada platform media sosial.

Sistem pelaksanaan kegiatan pameran yang diselenggarakan oleh UKM Multimedia ditentukan pada hari minggu, tanggal 8 Nopember sampai dengan hari senin, tanggal 9 Nopember 2020 bertempat di Aula ITB Stikom Bali. Pelaksanaan kegiatan dengan tenggang waktu yang sudah ditentukan, tentu sebelumnya sudah dirancang dalam perencanaan dalam rapat sesuai dengan pertimbangan-pertimbangan seperti, adanya kordinasi dengan pihak kampus, mempersiapkan karya-karya, dan sebagainya. Selain itu pentingnya mempersiapkan saranaparasarana dalam menunjang kegiatan lainnya seperti yang sudah tertera pada susunan acara di atas agar program kegiatan yang dirancang bisa berjalan sesuai dengan prosedur yang telah

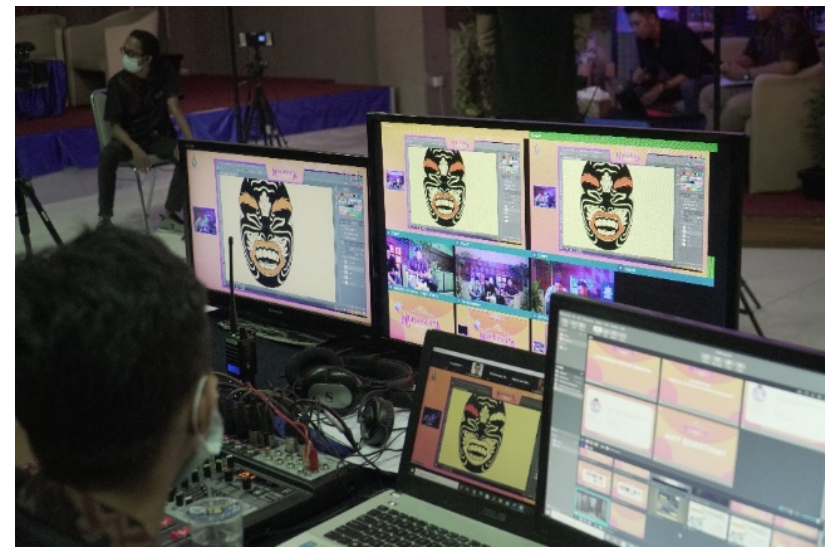

Gambar 2. Webinar dalam Pameran Digital. (Sumber: Penulis, 2020)

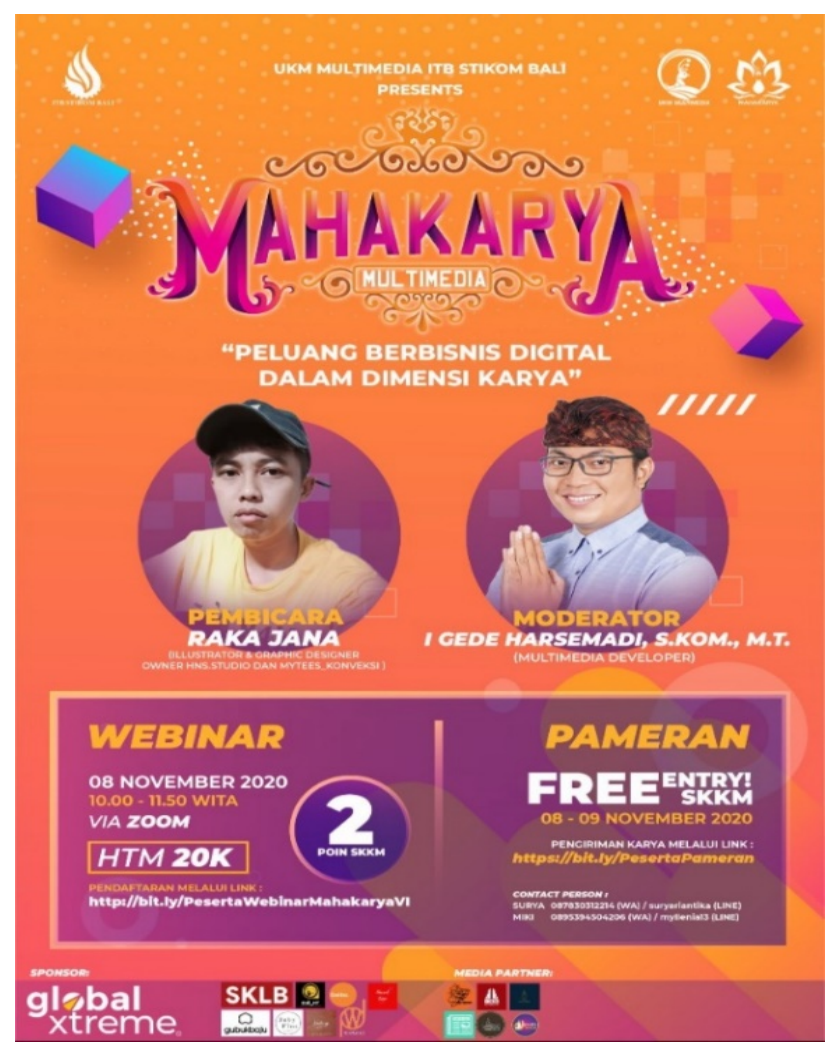

Gambar 3. Desain Media Elektronik

(Sumber: Panitia Pameran UKM Multimedia, 2020)

ditentukan.

\section{Sistem Publikasi}

Sistem publikasi sangat penting dalam menyebarluaskan informasi tentang penyelenggaraan pameran terhadap masyarakat luas melalui media elektronik seperti: Instagram 


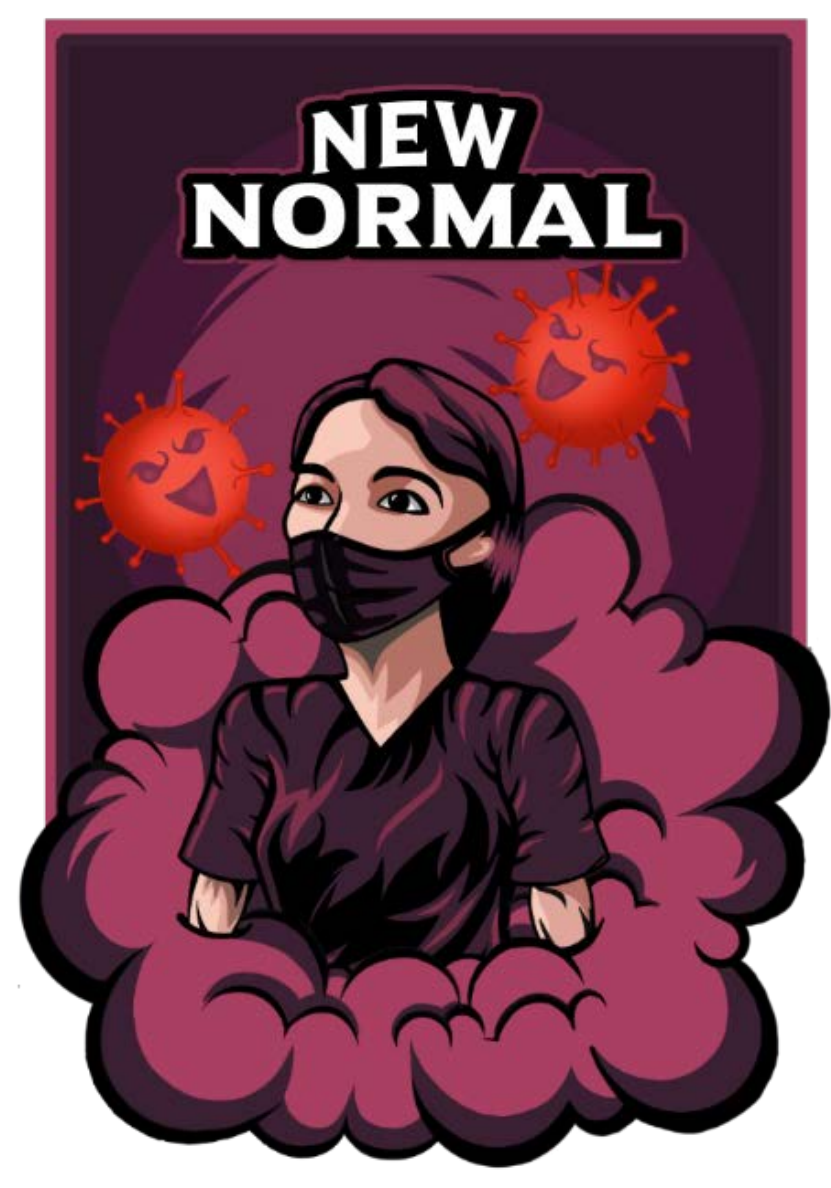

Gambar 4. Salah Satu Karya Peserta Pameran Digital. (Sumber: Panitia UKM Multimedia, 2020)

pada UKM Multimedia dan Instagram STIKOM Bali. Pada Gambar 2-4, ada beberapa desain yang sudah dibuat dan dipublikasikan dalam rangka penyelenggaraan pameran digital dan webinar. Berkaitan dengan pemajangan karya, pada masa pandemi seperti ini, tidak dilakukan sebagaimana biasanya. Pameran secara digital dipilih karena dipandang akan dapat mengurangi potensi penyebaran virus Covid 19.

\section{Kesimpulan}

Berkesenian tidak hanya berolah rasa dalam merealisasikan gagasan yang diekspresikan pada medium seni, akan tetapi, semuanya akan seimbang bilamana seorang kreator juga dapat mengelola gagasan, ketrampilan, publikasi, dan pemasaran sehingga terciptanya suatu mata rantai yang akan membuat kesenian itu tetap hidup. Pentingnya tata kelola seni dilaksanakan dengan merujuk pada teori manajemen adalah agar terdapat pedoman dalam pelaksanaan kegiatan. Keberhasilan organisasi dalam mengelola kegiatan yang dinilai dengan teori SWOT sangat penting dilakukan, karena dengan teori tersebut dapat teridentifikasi kelemahan, ancaman, kesempatan dan kekuatannya. Adapun Pengelolaan dalam pameran meliputi: adanya pengelolaan terhadap manusia, adanya perencanaan, pengorganisasian, pengumpulan sumber daya, pengendalian kerja, dan pengawasan. Hal tersebut penting diterapkan agar perencanaan pameran seni tepat dengan sasaran dan tujuan yang ingin dicapai. Tidak adanya batasan ruang dalam melaksanakan pameran seperti pada masa pandemi ini diharapkan dapat dijadikan sebagai salah satu solusi dalam berkarya.

\section{Ucapan Terima Kasih}

Kegiatan Pameran Digital Unit Kegiatan Mahasiswa (UKM) Multimedia Institut Teknologi dan Bisnis (ITB) STIKOM Bali periode 2019/2020 yang bertajuk MAHAKARYA MULTIMEDIA 2020 (Webinar dan Pameran Digital) ini terselenggara atas dukungan penuh Lembaga Penelitian dan Pengabdian kepada Masyarakat (LPPM) Institut Seni Indonesia Yogyakara, terutama dalam mempublikasikan tulisan mengenai acara kegiatan pameran ini.

\section{Kepustakaan}

Arikunto, S. (1998). Prosedur Penelitian Suatu Pendekatan Praktek. Jakarta: Rineka Cipta.

Handayaningrat, S. (1982). Pengantar Studi Ilmu Administrasi dan Management. Jakarta: Gunung Agung.

Hasibuan, M. (2014). Manajemen Sumber Daya Manusia. Jakarta: PT.Bumi Aksara.

Manullang, M. (2001). Manajemen Sumber Daya Manusia. Yogyakarta: BPFE-Yogyakarta.

Moleong, L. J. (2000). Metodologi Penelitian Kualitatif. Bandung: Remaja Rosdakarya.

Nazir, M. (2003). Metode Penelitian. Jakarta: PT. Ghalia Indonesia.

Prasetya, R. D. (2008). Aplikasi Model Pembelajaran Berbasis Masalah Pada Mata 
Kuliah Manajemen Di Bidang Desain Interior. LINTAS RUANG: Jurnal Pengetahuan dan Perancangan Desain Interior, 2(3).

Richard, D. (2010). Era Baru Manajemen. Salemba Empat: Edward Tanujaya
Setiarini, Agnes Tika. 2015. "Strategi Positioning dan Diferensiasi dalam Upaya Membangun Brand, Studi Kasus Ngayogjazz". Jurnal Tata Kelola Seni, Volume 1 No. 2 Desember 2015: 54-67. 